\title{
Capability of Students from the Low-socio-economic Backgrounds: Exploring Student Loans in Tanzania
}

\author{
Faustina M. Msigwa (PhD) \\ The Institute of Finance Management, 5 Shaaban Robert Street, P.O. Box 3918 Dar-es-Salaam, Tanzania
}

\begin{abstract}
Abstact
Higher education (HE) is expanding internationally driven by governments' dual concern to develop human capital that will contribute to economic growth and individuals' desire to expand their capabilities. However, as participation in HE expands, national governments are no longer able or willing to meet the costs but rather they prefer to use student loans strategy. This study explores how student loans decisions in Tanzania constrain or enhance capability of students from low-socio-economic backgrounds. The study is guided by Amartya Sen's Capability Approach (CA). Loan policy implementations are explored from the perspective of twelve students from low-socio-economic status (SES) backgrounds studying in the Universities of Dar-es salaam and Tumaini University Dar es Salaam. Through one to one in-depth interviews, they were invited to share their stories of applying for and distribution of loans. Findings show a discrepancy between the purposes of the financial assistance policy and the practice of loans distribution. The financial assistance policy, Higher Education Student Loans Board (HESLB) Act and HESLB regulations guarantee loans for poor students but in practice the proclaimed opportunity is unreliable. For instance, in 2017/2018 academic year loans were distributed based on clusters of academic programmes. The loans were guaranteed to students who are registered for education, Engineering, physical sciences and mathematics programmes only, grouped as cluster I and II. Chance to access loans for students who are registered for Humanities, Law, languages and other social science programmes, grouped as cluster III, is uncertain. This study recommends that, HESLB revise its criteria for issuance of loans in order to enhance capability of students from low- SES backgrounds of choosing to pursue their preferred occupations.
\end{abstract}

Keywords: Capability; Higher Education; Loans accessibility; Student loans; Student from low SES backgrounds.

DOI: $10.7176 / \mathrm{JEP} / 10-3-07$

\section{Introduction}

Higher education is perceived for example by the United Nations Educational, Scientific \& Cultural Organization (UNESCO) and the World Bank (WB) group to be vital for facilitating national growth, as well as the development of individuals and the society. The World Bank for example, incorporated this notion in its Africa Action Plan for 2006-2008 ${ }^{1}$ This Plan argues that HE plays a role in building skills and knowledge among individuals, which prepare them for roles as experts in diverse sectors of development. At a personal level, it allows graduates mobility, locally and internationally, and enables them to earn good incomes, which afford them social and economic well-being (Barr, 2005; Johnstone, 2006; Morley, 2007; Watson and Reisberg, 2011). Moreover, Walker and Boni (2013) explains that HE forms people's capabilities, such as their freedom to be and to do in ways they have reason to value (Sen, 1999), and to achieve wellbeing and agency thus, social arrangements are required to support capability formation. It is a concern of UNESCO and of human rights organizations that due to its role in facilitating individual, social as well as economic development, HE should be made accessible to all who have relevant academic qualifications (UNESCO 1998, article 3a).

In lower income countries, most of the young people who qualify cannot participate without financial support. In states where financial support is offered by the governments, they need to set a regulatory policy to ensure they are accessed by those with financial need (UNESCO, 1998; 2006; World Bank, 1998). In Tanzania, the use of student loan scheme is a common mechanism of distributing funds especially to students from the low socio-economic status (SES) backgrounds who are enrolled in the local HEIs.

However, previous research on Higher Education in Tanzania (Makulilo, 2010 and Msigwa, 2016a) show that loans distribution in the country are accompanied with the conditions which limit individuals from low SES backgrounds to access the facility. This study explores how student loan decisions in Tanzania constrain or enhance capability of students from low SES backgrounds. The study focuses on the opportunity of students from low SES to access student loans, to choose the programme of study, and join a career that they want. This study is of critical significance as it is expected to provide useful insights for HE planners and various education practitioners to enforce loan operation that enhances capabilities of the poor students.

This study uses concepts such as individuals from low-SES backgrounds, student loans, and accessibility of loans. In Africa, individuals from low-SES backgrounds are commonly identified according to parents' income

\footnotetext{
${ }^{1}$ Explanation is available at siteresources.worldbank.org/.../DC2007-0008(E)-AfricaActionPlan.pdf
} 
and the schools they have attended (Morley and Lussier, 2009). Most of them attend Government- owned schools which are less expensive. In the Tanzanian context, private schools charge high fees compared to government schools, thus, students who attend private schools are perceived to be from affluent families (Msigwa, 2016b). In the context of this study, students from low-SES background are defined as the poor, or individuals from low-income families. In Tanzania, students from low-SES backgrounds mainly attend government owned secondary schools which are found in every small residential unit, or ward. These schools are famously known as ward secondary schools. The schools are managed by the local government authorities, charge lower fees than government schools managed by the Ministry of Education or private schools. They are day schools and mainly admit students living within the locality. Ward schools are characterized by underresourced, poorly equipped classrooms, libraries, laboratories, and understaffing however, they are less expensive for low SES families. The mentioned characteristics of the ward schools adversely affect the academic performance of individuals from low-SES (Msigwa, 2016a). Whereas, students from wealthier families attend private schools which have good teachers and the best education facilities, the factors which enabled them to perform well especially in science subjects. In this study, the terms students from low- SES background', 'poor students' and 'students from low-income families' are used synonymously.

Student loans are defined as a way of offering financial support to students to cover part or total fees or living expenses basing on the decision made by the donor. The fund that covers fees may be paid to the HEI or given directly to a student. Loans always carry repayment obligations, which usually commence on completion of the degree (Organization for Economic Cooperation and Development, 1990). This study is concerned with a government loan fund which are given to students who are enrolled to both public and private HEIs. The HEIs verify the existence of the beneficiary students and disburse the living allowance to the students' bank accounts. To ensure sustainability of the loan scheme, the loan is repaid through an income- contingent contract and is repaid with "a Value Retention Fee (VRF) equivalent to $6 \%$ per annum from the date of receiving loan items...." (HESLB, 2018, p. 5).

Moreover, accessibility of a loans is referred to an opportunity to access part or full financial assistance from Government, which comes in the form of a loan as a means of supporting HE studies. The study focuses on loan accessibility for students, who have already been offered an undergraduate place at a HE institution that is recognized by Tanzanian statutory and regulatory organizations that have the mandate to oversee post-secondary education in the country, be it a public or private HEI.

\section{Genealogy of the establishment student loans in Tanzania}

Tanzania is a Sub-Saharan African country. According to the census of 2012 it has a population of 45 million people (National Bureau of Statistics, 2013). In a Tanzanian context, higher/ tertiary education refers to postsecondary education that is offered in colleges or universities, and leads to the awards of diploma, degree, post graduate diploma/degree or professional qualifications (United Republic of Tanzania, 1999).

\subsection{Historical back ground of HE in Tanzania}

During colonialism (before 1961), Tanzania then Tanganyika, was a British colony. Higher Education in the country was almost nonexistent. Individuals attended universities outside the East African region (Uganda, Kenya and Tanzania), (Omari, 1991). During this time HE was conducted under a free market economy (Bailey et al, 2011). The colonial masters were motivated to give some individuals the opportunity of receiving HE abroad, primarily to sustain personnel needs of the colonial regimes in the East African region. Following independence in 1961, a new University College of Dar es Salaam was formed, with only one Faculty- the Faculty of Law. The college was an affiliate of the University of London. A few other faculties were added later and formed the basis for the establishment of the East African University in 1963. Apart from Dar es Salaam as the main campus, the University had constituent colleges in Uganda (Makerere) and Kenya (Nairobi). Throughout the period of existence of the university, very few people in the region had access to it while some students came from outside East Africa (Omari, 1991; Bailey et al, 2011). It was Tanzania's Arusha Declaration that was announced in 1967, five years after independence, which proclaimed the inception of African socialism or Ujamaa. African socialism stressed training and employment of more African personnel which made it possible for many people to access the University of East Africa. Those who were not in the personnel training programme (especially those who were from meritocratic or elite families), financed their tuition (cost-sharing) (ibid, 2011). The University of East Africa was dissolved in 1970, and each campus formed an independent university. The split was due to Tanzania's aspirations to implement its socialist ideas to all levels of its education systems. The socialist ideas favoured state ownership of schools, higher education institutions, and the equitable distribution of the country's wealth. Basically, up to the beginning of 1990s there were only 2 universities in the Country, University of Dar es-Salaam and University of Sokoine, both were owned by the government. The first private university, Tumaini University Makumira, was formed in 1997. Today, there are 64 HEIs in the country, 43 public and 21 private (Tanzania Commission for Universities, 2018). 


\subsection{Cost sharing in Tanzania and establishment of student loans}

Cost-sharing policy in all social sectors in Tanzania including education, was re-introduced in 1988 as one of the features of a Structural Adjustment Programme, a programme introduced in low income countries to resolve the 1970s crisis. By this policy, the government was supposed to reduce its subsidy to public institutions. In 1992 the government began to implement cost-sharing in HE (Ishengoma, 2004; Bailey et al, 2011) which was implement in three phases. The first phase of its implementation started in the academic year 1992/1993. During this phase the parents were required to incur travelling costs for their children. The second phase of the cost sharing was implemented during 1993/94 academic year. In this phase students and their parents were supposed to incur the costs of meals, boarding, student union fees, and caution money (a refundable deposit paid once by a new student in case there will be property damage). During this phase, the government established student loans. The loans were given to all students enrolled in a reputable institution in Tanzania to cover their accommodation and meals. Items such as tuition, field, book and stationery allowances, registration, examination fees and other faculty requirements were covered by the government. Things went that way until the formulation of the National Higher Education Policy (NHEP) in 1999. The policy was established for the purpose of institutionalizing cost-sharing in the country.

The third phase went together with the introduction of the Higher Education Student Loans board, HESLB in 2004. During this phase students and their parents were required to pay for tuition fees, books and stationery, examination fees, field practical allowances and special faculty requirements. Distribution of loans by the HESLB started in July 2005; since then, loans were granted to all students enrolled in public and private institutions in the country to cover tuition and boarding. According to the policy (United Republic of Tanzania, 2008) Loans are granted only to students' who, due to their economic situation are unable to finance their HE. From 2007/2008 academic year the loan amount has been determined by the results from the means-testing, a formula used to determine student financial need.

However, distributions of student loans in Tanzania are guided by the criteria such as pursuing priority programmes: “... a student shall be given priority in consideration for loans if he (sic) is: ... pursuing or intending to pursue 'priority course' ...” (United Republic of Tanzania, 2008.p.6). Guidelines for distributions of loans further stipulates programmes clusters such as Health Sciences, Education (Sciences), Education (Mathematics), Civil and Irrigation Engineering, Petroleum and Gas Engineering... (HESLB, 2017; 2018), these are classified as cluster I programmes which means they are given priority in loans distribution. Literature of capability in Tanzania (Msigwa 2016a) shows that many of students from low SES backgrounds join 'priority programs' in order to access loan facility. It is thus vital to explore the viability of the existing loans distribution mechanism in enhancing the capability of students from low-SES backgrounds, which is the main focus of this study.

\section{Literature review}

Human capability plays a substantive role in development. Boni and Walker (2013) supports the importance of capability of individuals in attaining development. They connote "human capability formation is Human Development; human development demands human capabilities..." (Boni and Walker 2013, p. 8). Hence, governments, universities and all the institutions that deal with HE should take an active role in performing actions that support peoples' capability such as ensuring freedom for everyone to enjoy valuable functionings. The following literature presents a debate on whether $\mathrm{HE}$ is a right or a tradable commodity. Furthermore, the literature reviews the ideas on whether HE is a tool for enhancing capability, and how various practices constrain or enhance capability of individuals from the low SES backgrounds.

\subsection{Higher education a right or a tradable commodity?}

A question on whether HE is a right can be situated in a debate on whether HE is a right (public good) or a tradable good. Neo-liberal economists (for example Chutikul, 1987; Knight, 1989 and Baum et al, 2010) argue for HE to be a tradable good; they see it as having an individual benefit, for example, in building individual skills and knowledge that enhance personal career prospects. They further argue that private investments in HE serves as a potential solution to many financial problems and it has superior outcomes than that of public investments.

The Universal Declaration of Human Rights proclaims that "everyone has the right to education, and that technical and professional education shall be made generally available... and HE shall be equally accessible on the basis of merit" (Universal Declaration of Human Rights 1948, Article 26, 1) The assertion suggests that, states need to employ initiatives toward increasing HE accessibility to consider equality and equity. The "World Declaration on HE for the twenty-first century: vision and Action" (UNESCO, 1998) affirmed participation in $\mathrm{HE}$ as a right, and 'equity of access as central to it. Arguing that HE contributes to an individual's well-being as well as social and economic development liberalists (such as Jongbloed, 2004; Makulilo, 2010 and Morgan, 2011) explain that it is essential that every qualified individual should have access to it. They consider that 
public funding for HE is essential in ensuring equality and equity of access. Based on liberalists' argument of the importance of HE to individuals and to the society, I support that States have a role to play in subsidizing it. Among the many initiatives that the Tanzanian government has taken to widen HE participation is to support the needy students by giving loans. Given that student loans in Tanzania are a public resource, it is the right for every needy individual to have an access to these loans. Further, I perceive the government's provision of loans is one way of redistributing the finance contributed by its citizens through taxes. Thus, students from the lowSES backgrounds in Tanzania have the right to access this resource and to claim for it.

\subsection{The role of higher education in enhancing capability}

HE has a benefit to the society at well as to individuals. To individuals it gives those who have achieved it a wide range of life chances and flexibility of entry and exit points of their employment (UNESCO, 1998. To the society it adds to the world of knowledge and understanding. HE can also help to reduce or alleviate social problems such as crime, disaffection and illiteracy. More over at a personal level, HE is regarded as important due to its role in bringing the intellectual development of an individual (Barr, 2005; Johnstone, 2006; Watson and Reisberg, 2011). Furthermore, HE guarantees capability of an individual, such as an ability to attain valued effects and opportunities (Greenstone and Looney, 2012). Boni and Walker (2013) give an example of attainment such as enabling individual's mobility locally and internationally and providing good income which result to individual social and economic well-being.

Walker (2003) discusses the role of HE by asserting that human capital is one goal of HE because skilled people are able to fit well in income generation. However she comments that although human capital is essential goal for education but income alone or economic growth cannot constitute the full well-being of an individual. United Nations Development Programme (UNDP) connotes, people requires to have intellectual capability to enable their freedom to choose and pursue their economic and social ambitions (UNDP, 1990). Thus, states need to have education policy that enables all to have equal access to opportunities. In the context of this study human capability perspective of the role of HE is applied in exploring about how do student loans decisions constrain or enhance individual's opportunity of an individual to reach to a desirable end, i.e. freedom to choose to study what he/she is aspiring to do and to be. This connects to opportunity of an individual to choose and realize goals that he/she has reasons to value (agency).

Mukherjee (2010) explored initiatives for increasing access to HE in Malaysia. Mukherjee (2010) explains that, all qualified individuals in Malaysia enjoy the opportunities to study at the local HEIs and abroad. However, World Bank (2011) reports that in Malaysia, students from low SES backgrounds are rarely enrolled in disciplines which promise high returns such as engineering, physical sciences and medicine, while wealthier students dominate such fields. Perdana Leadership Foundation (2011) recommends a need for further arrangements to ensure equality of opportunity of accessing all the fields. Asian Development Bank (2012) suggests the use of special financial incentives for all who have relevant academic qualification. The strategy can be used to enhance equality of joining fields which promise high returns.

Strydom (2011) provides a theoretical argument in supporting capability framework as useful in understanding complex environment in making HE successful. She argues that providing access and financial support to HE is important but not sufficient in realizing capability to an individual. The systems are required to go beyond access and consider personal, social and environmental factors of an individual. Strydom recommends that in understanding the role of $\mathrm{HE}$ in attaining capability, one is required to think beyond achieving outcomes, but real freedom and opportunities that will be available for each individual to choose and to achieve what he/she values.

The above literature show a support of the right for everyone to perform actions that are valuable to him/her. In HE context, the above literature emphasize freedom of individuals to choose to study subjects of their interest, and that they think promise them a good future or well-being (capability). However, although the issue of loans policy in Tanzania and how it affects accessibility of students from the low SES backgrounds has been discussed by previous researchers (Makulilo, 2010 and Msigwa, 2016a), the issue of capability of these students has not been discussed. This study explores how student loan decisions in Tanzania constrain or enhance capability of students from low SES.

\section{Theoretical framework}

This study is guided by Sen's Capability Approach (1999). Amartya Sen is a prominent philosopher of the late $20^{\text {th }}$ and early $21^{\text {st }}$ centuries, who owns remarkable works in the field of development economics. Sen is the main founder of Capability Approach.

Formulation of capability have two parts: functionings and opportunity freedom/agency. Functionings are outcomes that people value and have reason to value, these are things that are feasible to achieve. For example being nourished, being literate, having a good salary or a fulfilling employment. However functionings are not limited, are also include being happy, having good reputation and fun, warm friends and so on. The capability 
approach raises the issue of what process, group, philosophical structure or institution has the legitimate authority to decide what people have reason to value. But while the capability approach argues that public debate and critical scrutiny are often helpful it stops well shot of proposing one particular process as relevant in all contexts, and rather depends on the agency of people acting in those contexts to address these questions themselves and build up and share their repertoire of good practices.

Furthermore, capabilities are the freedom to enjoy valuable functionings so, they combine functionings with a kind of opportunity freedom, and such as a substantive freedom of a person to lead a kind of life he/she has reason to value (Sen 1999, p.87). Is just like a person having a bag full of money can elect between many different functionings and pursue a variety of different life paths. Capabilities are thus described as the real and actual possibilities open to a given person (opportunity). Sen (1999) has developed his Capability Approach arguing that people in a society should have equal opportunity to live the kind of life they have reason to value. For many young academically qualified people in Tanzania, this includes the opportunity to choose to pursue the academic programme they want in HE and fulfil their aspirations.

Moreover, Sen and Nussbaum (Sen's core founder of capability approach) have stressed the importance of individual agency, this encompasses individual freedom to decide matters that shape one's own life. According to Sen, people have to be given the opportunity -in shaping their own destiny, and not just as passive recipients of the fruits of cunning development programs (Sen, 1999p. 53). UNDP (1990p. 9) adds to Sen's fact that human development is a process of enlarging peoples choices. From this perspective development relies on peoples' freedom to make decisions that shapes their own lives. They themselves decide upon what kind of development they would like for themselves.

Basically, the significance of factors of functions and agency is that they indicate how fair is the distribution of opportunities for individuals to exercise their rights to choose the kind of life that they have reason to value (capability). The Capability Approach becomes relevant to this study as it addresses issues of the influence of loans decisions in Tanzania on opportunities of individuals from low SES backgrounds to choose the programme they want to study as long as they qualify, and their freedom to join the occupation they want. Strydom suggests, "Capability approach...is particularly useful in the context of an unequal education system, and in seeking to formulate ways in which to enhance the capabilities of those who currently have limited options" (Strydom 2011, p. 412)

\section{Methodology}

This study applies an interpretive design. Interpretive approach is used to obtain information and understand a situation or phenomenon through the meaning assigned to the situation by the participants (Labaree, 2013). Interpretive approach is used in this study to engage with the perspectives and experiences of $20 \mathrm{HE}$ students concerning student loans distributions and their freedom to choose to study what they want. Student participants are studying at the University of Dar es Salaam (UDSM) and Tumaini University-Dar es Salaam College (TUDARCO). These institutions (UDSM and TUDARCO) were selected because they are the oldest public and private (respectively) in Tanzania. They run many, different academic programmes, and thus it became possible to access students' from diverse academic programmes, who have and who do not have loans access, and to conduct in depth interviews with them and to obtain their perspectives and experiences with the student loans distributed by HESLB.

Many researchers (Bertaux, 1981; Cresswell, 1998; Shari, 2012) suggest 5 up to 25 interviews as adequate for fulfilling the aim of understanding individual's perspectives and experiences. This study involved 12 student participants, 6 from the UDSM and 6 from TUDARCO. The sample selection considered students from low-SES backgrounds (defined in section 1), 8 who accessed the loans at different levels, and 4 who do not have access to the loans. All of the selected students were pursuing bachelor degrees in the named institutions. The loans issuing guidelines document (HESLB, 2016) indicates that only undergraduate students are accessing the loans based on family economic status. In the selection of student participants, I also considered programmes in which they are enrolled. I selected 6 students who were pursuing government 'priority' programmes, such as science, mathematics and education, and 6 who are doing 'non-priority' programmes such as humanities.

\subsection{Data collection and analysis methods}

This study uses semi-structured, one to one in depth interviews. Semi structured interviews are flexible (Bryman, 2008) as they allow for informal conversations, and discussions. Informal conversations give respondents freedom for self-reflection. During the interviews I asked student participants to explain their perspectives of the loan's policy implementations specifically, about their perspectives on whether loans decisions constrain or enhance their freedom to participate fully in HE. This discussion embeds Sen's capability approach regarding their freedom to choose and access the academic programmes they want to study as long as they qualify to pursue the programmes.

The study uses thematic analysis as employed by Braun and Clarke (2006) to analyse data collected through 
interviews with students. As defined by Bryman (2008), and Braun and Clarke (2006), thematic analysis is the process of identifying, analysing and reporting key aspects or patterns found within the collected data. Braun and Clarke's approach to thematic analysis is flexible and can be used with several epistemological approaches. Thematic analysis has potential in allowing categories/themes to come out of the data, and understand the meaning deriving from its context. The method is more appropriate for analysing personal data about individuals' own experience and life style. Thus it has potential for analysing interview accounts of students from low-SES backgrounds about their perspectives and experiences of loan policy and practice with regard to their accessibility and participation in HE. With respect to thematic analysis, in the present study the experiences and perspectives of students are featured as themes. In the processing of the data and the performing of thematic analysis, NVivo computer software package was used to simplify the process of coding and analysis.

\section{Findings and discussion}

Experience from the field reveals that loan decisions in Tanzania, are made by loans allocation officers in HESLB, hence the concern of this study is to explore the extent to which loan decisions constrain or enhance an individual's capability to participate fully in HE. To participate fully includes students' freedom to choose what they want to do and be in their future. By using Sen's capability approach (Sen, 1999) this section presents students' experiences about their opportunity to choose the programme they want to study, and choose for their future career.

\subsection{Students' opportunity to choose their programme of study.}

Students' experiences show that when they make applications to join HE, they are required to choose the programmes they wish to study, as long as one has a background in the field and a good pass at Advanced Secondary school level. So, in the selection, students are chosen according to what they have applied for. Referring to this experience, it appears as if freedom of choice for students is respected.

In the loan policy and its implementations programmes have been put into clusters I, II and III (HESLB, $2017 ; 2018)$ such as the programmes which are in cluster I are given priority in loans distribution and so on. This necessitates a need to explore whether the clustering of programmes influences students' freedom to choose their programme of study. Participants such as Alieda, Jumbe, and Daniel revealed the tendency of students to choose to study programmes which are categorized into cluster I for the reason of accessing loans. This was confirmed by Mpaya and Zaara who opted to pursue an education programme (they do not qualify to take for example, medicine or engineering) to access loans. The following extracts show their explanations:

...I was advised by my relatives to take this programme because it is a government priority in loans distribution... (Extract from an interview with Alieda, 2017).

My plan was to take Bachelor of Law. But when I came across the guide book, I found Law falls under cluster III. Thus, I had no choice than to applying for education programme which falls under cluster I.... (Extract from an interview with Jumbe, 2017).

...I agree that loans issue influence students to opt cluster I courses. For example my case, it was not my intention to take BA (Ed), but I opt it because I was targeting to access the loans, since my parents do not have such financial capability ... Extract from an interview with Daniel, 2017).

Although Katembo is doing a "cluster I programme" he still think that is not fair for the government to distribute loans basing on "clusters" see the following exerpt:

Although I am doing education, but I think distributing loans basing on "programme clusters" is not right. I advise HESLB to grant loans to all poor students who have been enrolled in a HEIs. I mean loans to be granted to all needy students who are admitted to HE regardless of the enrolled programme. (Extract from an interview with Katembo, 2017)

The following student, from a really poor family was denied a loan after being admitted to a 'non-priority' programme.

I am in my first year, doing B.A (economics)...Regarding loans distribution, I find it is not clear. I studied in a public school (in Advanced Secondary school level) and passed, but I was not granted the loan. I made follow up they told me that the loans were first granted following clusters, and to the disabled... (Extract from an interview with Mpaya, 2017).

Another participant explains that she had to postpone her studies and take a temporary job. The next year she decided to change programme and opt the top most cluster programmes in order to access the loans. She explained:

In 2015 I applied B.com (Accounting) I did not succeed to access the loans, so I got a school to teach temporarily, is where I got to like teaching. In 2016 I re-applied for Education course and it has made me access the loans (Extract from an interview with Zaara, 2017).

The above illustrations confirms that, in Tanzania, students from low-SES backgrounds, most of whom did 
not study science subjects at Advanced Secondary education level, opt to pursue education which falls under 'cluster I' programmes in loans distribution. This implies that when they apply for HE, they choose to pursue programmes which they think will enable them to access the loans, and not those which are of personal interest and which promise them a good future and their well-being. Taking example from the above explained experience of Zaara, she really aspired to do accounts. She applied and was admitted; the problem with her choice was that she could not access loans if she was going to study the programme. She was thus forced by the situation to re-apply for the 'cluster I' programme (education), which she was able to access the loans. Hence, the findings of this study indicate that the loan scheme in Tanzania does not consider the freedom of young people from the low-SES backgrounds to choose what they want to study. It gives loan accessing priority to applicants who are enrolled in STEM programmes and only education for non-science programmes, something which limits choice for poor non-science students. Furthermore it appears that, the created opportunity for the national 'priority' programmes (cluster I) allows many loans accessing chances to be taken by students from wealthy families. These students have attended good schools (most of which are private and some are well performing public schools). The schools have good teachers and the best education facilities, the factors which enabled the students to perform well especially in science subjects. This clue corresponds with the current (2016) Advanced Certificate of Secondary Examination results ${ }^{1}$, which shows that private schools are performing better than government schools, especially in science subjects.

\subsection{Students' opportunity to choose their future careers.}

HE is understood as a level that prepares young people to acquire qualifications to enable them to pursue various professions. In the previous section, it has been shown to ensure capability, it is necessary for an individual to have freedom to choose a discipline that he/she feels is right for him/her. Capability in this study is also viewed from the perspective of the availability of students' freedom to choose disciplines for their future careers. An interview with students revealed that in Tanzania, since young people from low-SES backgrounds depend on student loans to finance their HE, their freedom to choose their future careers is sacrificed to access loans. This is evidenced by the following students' accounts:

... I opted education because it falls under cluster I in loans distribution... and also when I complete my studies I can easily get employment. (Extract from an interview with Matias, 2017).

Today I am doing a course which I don't like... I had never thought of becoming a teacher, I do not have an ambition to become a teacher... (Extract from an interview with Mawazo, 2017).

The following students said they qualified to access the loans but they were denied because the programmes they were admitted to are not priority in loans distribution:

...In my case, I was advised by my relatives and friends that when I take education I can easily access the loans, I did not like Education at all so I didn't choose it...as a result I was not given the loans (Extract from an interview with Juya, 2017).

Although I face difficult times in surviving without loans, I cannot apply for teaching...If I go to teach, do you think my students will understand what I'll be teaching? One cannot do something perfectly unless he/she has chosen to do it, and is proud of it... (Extract from an interview with Winnie, 2017).

The following students explain their opinion about the consequences of forcing people (through loan accessing criteria) to join a profession (teaching) in which they lack genuine interest:

I did not like this course, so I will drop it after graduation. When I have a degree it is easy for me to get another job than teaching... (Extract from an interview with Jalia, 2017).

I think most of those who also dislike education will find other jobs than teaching because, apart from education subjects they are doing other subjects as well... (Extract from an interview with Matias, 2017).

The impact is very clear, the government is producing teachers who do not have interest with the profession. (Extract from an interview with Asia, 2017).

Producing teachers who do not have an interest with the profession may result to falling of education standard (Extract from an interview with Jumbe, 2017).

The above extracts imply that not all poor students who are choosing to pursue education genuinely want to pursue the teaching profession. From students' accounts it appears that the wards secondary schools in Tanzania face the problem of teachers' shortage. Therefore, the government is trying to train as many teachers as possible to fill the gap. The problem of teachers' shortage is not a problem exclusive to Tanzania, it is prevalent worldwide and especially acute in the SSA region (Msigwa, 2016a). Students explain that, although some wish they

\footnotetext{
${ }^{1}$ The 2016 national examination results are available at http://www.necta.go.tz/results2016/ACSEE2016/index.htm , the summary of school ranks in overall, and by subject can also be viewed at http://opendata.go.tz/dataset/nafasi-za-shule-katika-mitihani-ya-taifa-ya-kidato-chasix/resource/ df600027
} 
could pursue other professions like management, law, accountancy or medicine, they cannot because the humanities and social sciences are not allocated in upper clusters which can guarantee accessibility of loans. Furthermore, they cannot think of applying for science programmes because some of them do not have science background in their Advanced Secondary school level, and others do not have sufficient credits in the subjects and therefore do not qualify to pursue science programmes in HE.For example, to be admitted to pursue a degree of medicine and allied sciences an applicant is required to have three principal passes in physics, chemistry and biology subjects with a minimum of 8 points as indicated by the Tanzania Commission for Universities (TCU) guidance book (TCU 2018). These students find themselves with only one option, education, which involves both science and non- science programmes. It is nevertheless the right of an individual to exercise his/her freedom capability of choosing the occupation he/she wants. I believe if the poor students could get the opportunity to choose to study and do the occupations that reflect their interest they could enjoy it. The role of government should remain to help these young poor people to compete for better paid occupations which would enable them to find their way out of poverty. For the government to enroll many students to pursue education is not a guarantee that the teachers' shortage problem will be resolved. UNESCO (2014) suggests comprehensive investment in both training and incentives in the form of good salaries and attractive career paths. However not all students from low-SES backgrounds who opt to pursue education do so because of the loan accessibility criterion. Some have a genuine desire to become teachers or education officers. This is evidenced by students like Katembo and Zaara after pursuing the job for one year (see section 6.1), who applied for education programme because of their enthusiasm for the profession.

\section{Conclusion and recommendations}

This study explored how student loan decisions in Tanzania constrain or enhance capability of students from low SES. The study focuses on the opportunity of students from low SES to choose the programme of study and join the career they want. Worldwide there is a shortfall in the number of teachers (UNESCO, 2014). The greatest teachers' shortfall challenge is in the Sub-Sahara African region which is required to raise teachers' resource by 63 percent by 2030 which accounts for half of the total additional secondary teachers required (ibid, 2014).

The initiative to raise the teachers' resource base in Tanzania (particularly at a degree level) has taken an imperative of the government to assign education as among the 'cluster I' programmes in students financing (section 2.2). Most of the low-SES students who are granted government loans are enrolled in education programme (Msigwa, 2016a). Teaching in Tanzania, like other African countries, has a reputation for poor remuneration compared to other graduate professions (UNESCO, 2014). Allocating programmes in clusters for loans distribution has an impact on professional practice and on understanding of the society. It implies that the state will end up with a cohort of engineers, doctors, managers and lawyers and all 'better paid occupations' who come from affluent backgrounds.

The Tanzanian government might have good intention of investing in producing professions with a huge human resource gap, but the way this strategy is linked to student loans which are intended to support individuals from poor families, it may imply otherwise. As an un-intended consequence, it looks as if the poor are being pushed to low paying occupations. As Archer connotes, “... in all stages within the educational journey, young working class (the disadvantaged) people experience poorer conditions, receive fewer resources, study for less prestigious qualifications and follow lower status trajectories" (Archer, 2003, p.5). I thus advise the Tanzanian Government and other governments which use similar loan scheme to rethink combining two missions in one funding programme (such as to support students' from poor families; support students' who are enrolled in occupations which have acute shortage). Guaranteeing loans to students of only a few academic programmes denies capability to students from low SES backgrounds to choose to pursue the career that they want.

\section{References}

Archer, L. (2003) "Social class and Higher Education" In L. Archer, M. Hutchings, A. Ross (Eds), Higher Education and Social Class: Issues of Exclusion and Inclusion. London: Routledge Falmer, pp.5-20.

Asian Development Bank, ADB. (2012). Access without Equity? Finding a better balance in Higher Education in Asia. Phillipines: Asian Development Bank.

Bailey, T., Cloete, N., Pillay, P. (2011). Universities and Economic Development in Africa; Tanzania and University of Dar es Salaam. Cape town, South Africa: The Centre for Higher Education Transformation.

Barr, N. (2005). "Financing Higher Education" In Finance and Development: a quarterly magazine of the International Monetary Fund, 42 (2). Retrieved on $2^{\text {nd }}$ November, 2011 from http://www.imf.org/external/pubs/ft>

Baum, S., Ma, J., and Payea, K. (2010). "The benefits of Higher Education for individuals and societies" Education pays 2010: Trends in higher education series. New York: college Board, advocacy and policy center.

Bertaux, D. (1981). "From the life story approach to the transformation of sociological practice" in D. Bertaux 
(Ed), Biography and society: The life history approach in the social sciences, London: SAGE, pp. 29-45.

Boni, A and Walker, M. (Eds). (2013). "Introduction" Human development and capabilities: Re-imagining the Universities of the twenty-first century. 2 Park square, Abingdon: Routledge.

Braun, V., and Clarke, V. (2006). "Using thematic analysis in psychology" Qualitative Research in Psychology, 3(2) pp.77-101.

Bryman, A. (2008). Social Research Methods 3rd Ed. New York: Oxford University Press Inc.

Chutikul, S. (1987). "The economics of Education subsidies and the effect of fee increases: A case study" Discussion paper series number 93, Faculty of economics, Bangkok: Thammasat University.

Cresswell, J. (1998). Qualitative inquiry and research design: choosing among five traditions. Thousand Oaks, CA: SAGE.

Greenstone, M. and Looney, A. (2012). Regardless of the coast, college still matters. Massachusetts: Hamilton project.

Higher Education Students Loans Board. (HESLB). (2015). Guidelines and criteria for issuance of student loans and Grants for 2015/2016 academic year. Dar es Salaam: HESLB. Retrieved on $21^{\text {st }}$ May 2015 from http://www.heslb.go.tz

Higher Education Students Loans Board. (HESLB). (2016). Guidelines and criteria for issuance of student loans and Grants for 2016/2017 academic year. Dar es Salaam: HESLB

Higher Education Students Loans Board. (HESLB). (2017). Guidelines and criteria for issuance of student loans and Grants for 2017/2018 academic year. Dar es Salaam: HESLB. Retrieved on 11th June 2017 from http://www.heslb.go.tz

Higher Education Students Loans Board (HESLB). (2018). Guidelines and criteria for issuance of student loans and Grants for 2018/2019 academic year. Dar es Salaam: HESLB. Retrieved on 13th July 2018 from http://www.heslb.go.tz

Ishengoma, J.M. (2004). “Cost Sharing in Higher Education in Tanzania: Fact or Fiction?” Journal of Higher Education Administration, 2 (2), pp. 101-133.

Johnstone, B. (2006). Financing Higher Education: Cost-sharing in International Perspective. Boston: Boston College Centre for International Higher Education. Rotterdam: Sense Publishers.

Jongbloed, B. (2004). "Funding Higher Education: options, trade-offs and dilemmas" New Trends in Higher Education. Paper for Fulbright brainstorms. Retrieved on $3^{\text {rd }}$ March, 2014, from http://doc.utwente.nl/56075/1/engpap04fundinghe.pdf.

Knight, J. (1989). "Educational policy issues in a period of stabilization and structural adjustments" Journal of Development planning, 19: 59-72.

Labaree, R. (2013).Types of research designs. Retrieved on $11^{\text {th }}$ June, 2013 from http://libguides.usc.edu.writing guide.

Makulilo, V. (2010). Private Financing in Tanzania: A Restraint on Democratization of Higher Education Access by the Poor? M.A Dissertation, University of Dar es Salaam. Unpublished. Retrieved on 12 ${ }^{\text {th }}$ April, 2013 from http://redet.udsm.ac.tz/documents storage/2010

Morgan, J. (2011) "Knowledge without borders: Higher Education, Human Right or Tradable commodity?" UNESCO chair of the political Economy of Education. The University of Nottingham. Retrieved on $20^{\text {th }}$ February, 2013 from www.nottingham.ac.uk/education/he-as- human-right-or-tradable...

Morley, L. (2007). "The X factor: employability, elitism and equity in graduate recruitment". $21^{\text {st }}$ century society: Journal of the Academy of social sciences, 2 (2), pp. 191-207.

Morley, L., and Lussier, K. (2009). "Intersecting poverty and participation in Higher education in Ghana and Tanzania" International studies in sociology of education, 19 (2), pp. 71-85.

Msigwa, F.M. (2016a). Widening participation in Higher Education for students from the low socio-economic status group?: A Social Justice analysis of student loans in Tanzania. A dissertation submitted in the University of Bristol for a degree of Doctor of Philosophy. Unpublished.

Msigwa, F.M. (2016b). "Widening participation in Higher Education: a social justice analysis of student loans in Tanzania" The International Journal of Higher Education Research, 72 (4), pp. 541-556.

Mukherjee, H. (2010). "Access to and equity in higher education: Malaysia" Background paper prepared for World Bank 2011. Washington, DC: The World Bank.

National Bureau of Statistics. (NBS). (2013). Tanzania National data. Retrieved on $12^{\text {th }}$ November 2013, from http://www.nbs.go.tz.

Organization for Economic Cooperation and Development-OECD. (1990). Financing Higher Education, current patterns. Paris: OECD.

Omari, I.M. (1991). "Innovation and change in Higher Education in Developing countries: experiences from Tanzania” Comparative Education, 27 (2), pp. 181-205.

Perdana Leadership Foundation (2011). "Higher Education in Malaysia: Increasing access equity" Keynote address by Dato Seri Mohamed Khaled Nordin. Perdana Discourse series, 12/2011. 
Sen, A. (1999). Development as freedom. Oxford: Oxford University Press.

Shari, L. (2012). "Sample size policy for qualitative studies using in-depth interviews" Archives of Sexual Behavior, 41 (6), pp. 1319-1320.

Strydom, M.W. (2011). "University access for social justice: a capabilities perspective" South African Journal of education, volume 31, pp 407- 418.

Tanzania Commission for Universities (TCU) (2018). List of Undergraduate Degree Programmes Approved to Admit students in 2018/2019 Academic year. Dar es Salaam: TCU. Retrieved on $22^{\text {nd }}$ July 2018, from cas.tcu.go.tz/assets/images/undergraduate_admission_guidebook_2018_2019.pdf.

UNESCO. (1998). "World Conference on Higher Education in the Twenty-first century: Vision and Action". Paris: UNESCO. Retrieved on $1^{\text {st }}$ October 2012, from http://unesdoc.unesco.org/images/001163/11.

UNESCO. (2014). Education for All Global Monitoring Report. 'Teaching and Learning: Achieving Quality of Education for All' UN Educational Science and Cultural Organization. Retrieved on $14^{\text {th }}$ June 2014, from http://unesdoc.unesco.org/images/0022/002266//226662e.pdf.

United Nations Development Programme (UNDP), (1990). Human Development Report 1990: Concept and measurement of human development. New York: Oxford University Press.

United Republic of Tanzania (URT). (1999). National Higher Education Policy. Dar Es Salaam: Ministry of Science Technology and Higher Education.

United Republic of Tanzania. (URT). (2008). Act number 9 of 2004 CAP 178, section 33, Regulation. Dar es Salaam: Ministry of Finance.

Walker, M. (2003). "Framing social justice in education: what does the 'capabilities' approach offer?" The British Journal of Educational Studies, 5 (2), pp. 168-187.

Walker, M and Boni, A. (2013). "Higher education and human development: Towards public and social good" In A. Boni and M. Walker (Eds), Human development and capabilities: Re-imagining the Universities of the twenty-first century. 2Parksquare, Abingdon: Routledge.

World Bank (1998). "Knowledge for Development". World Development Report. Washington D.C., USA: World Bank and Oxford University Press.

World Bank. (2011). "Financing Higher Education" Retrieved on 24 ${ }^{\text {th }}$ June 2015, from http://www. Siteresources.worldbank.org/EASTASIAPACIFICEXT/Resources/2263001279680449418/EAP higher_education_chapter4.pdf.

Watson, D and Reisberg, $\bar{L}$ (2011) "Access and Equity" In Phillip Altback (Ed),.Leadership for world class universities: Challenges for developing countries New York and London: Routledge. 